\title{
Potential Use of Biosolids to Reforest Degraded Areas with New Zealand Native Vegetation
}

\author{
María Jesús Gutiérrez-Ginés, ${ }^{*}$ Brett H. Robinson, Juergen Esperschuetz, Engracia Madejón, \\ Jacqui Horswell, and Roger McLenaghen
}

\begin{abstract}
Biosolids could potentially be used for reforestation of degraded soils in New Zealand with native vegetation. Many native plant species of New Zealand thrive in low-fertility soils, and there is scant knowledge about their nutrient requirements. Therefore, it is unclear whether they will respond positively to the addition of biosolids. We used a pot trial to determine the responses of 11 native plant species to biosolids addition (10\% w/w, 90 Mg $\mathrm{hm}^{-2}$ ) on two distinct degraded soils, Lismore stony silt loam and a Kaikoura sand. We also intended to prove that the soil microbial activity improves with the addition of biosolids, depending on the plant species. All species grew better in Lismore stony silt loam than the Kaikōura sand. All species in the Lismore stony silt loam responded positively to biosolids. The response to biosolids addition in the Kaikōura sand was variable, with four species showing no improvement in growth when biosolids were added. The nutrient status (N, P, S, Cu, and $\mathrm{Zn}$ ) of all species improved when the two soils were amended with biosolids. However, some plant species, especially Pittosporum tenuifolium Sol. ex Gaertn. and Coprosma robusta Raoul, showed concerning concentrations of $\mathrm{Cd}$ (up to $2.4 \mathrm{mg} \mathrm{kg}^{-1}$ ). Dehydrogenase activity of soils (indicator of soil microbial activity) increased in biosolidsamended soils, with a strong species effect. Future work should involve field trials to determine the effect of biosolids addition on the establishment of native plant communities.
\end{abstract}

\section{Core Ideas}

- Adding biosolids to two low-fertility soils had contrasting effects on NZ species.

- N, S, P, Cu, Mn, and $\mathrm{Zn}$ concentrations were higher in plants treated with biosolids.

- New Zealand native dicots accumulated more nutrients than native monocots.

- Trace element accumulation by some species may present an ecological risk.

- In ecosystem restoration, biosolids may favor weed growth over NZ native plants.

Copyright $\odot$ American Society of Agronomy, Crop Science Society of America, and Soil Science Society of America. 5585 Guilford Rd., Madison, WI 53711 USA.

All rights reserved.

\section{J. Environ. Qual. 46:906-914 (2017)}

doi:10.2134/jeq2017.04.0139

This is an open access article distributed under the terms of the CC BY-NC-ND

license (http://creativecommons.org/licenses/by-nc-nd/4.0/)

Supplemental material is available online for this article.

Received 10 Apr. 2017.

Accepted 5 June 2017

*Corresponding author (maria.gines@esr.cri.nz).
O oll degradation is a global environmental issue affecting up to 6 billion ha (Gibbs and Salmon, 2015). In New $\bigcup$ Zealand (NZ), some 2.5 million ha of soil are formerly or currently under pine plantation. Due to the falling price of pine (Pinus L. spp.) timber, there is little incentive to replant these degraded soils in pine forests. Former pine forest soils have low organic matter (OM) and nutrients contents. Plantations with non-native species can decrease $\mathrm{OM}$, and harvesting plantations can result in the near-total loss of topsoil (Jurgensen et al., 1997; James and Harrison, 2016). Potentially, the restoration of such degraded soils could be achieved through the addition of exogenous OM (Meyer et al., 2004).

In countries with wastewater treatment facilities, the average fresh sludge production per capita is $\sim 52 \mathrm{~kg} \mathrm{yr}^{-1}$, which results in a global output exceeding $10 \mathrm{Tg} \mathrm{yr}^{-1}$ (Bradley, 2008). Studies about land application of sewage sludge and treated municipal wastewater started in the early 1960s Pennsylvania State University. These studies demonstrated the benefits of reusing and recycling those materials on soil physical, chemical, and biological properties (Sopper and Kardos, 1973). Biosolids is a term coined in the United States that is typically used to describe several forms of treated sewage sludge that is intended for agricultural use as a soil conditioner. This treated sewage sludge-or biosolids-can improve the nutrient status of soils and enhance the growth of plants and microbial communities (Singh and Agrawal, 2008). Biosolids have been used worldwide to establish herbaceous native vegetation on degraded soils, such as fire-affected forests (Meyer et al., 2004), quarries (MorenoPeñaranda et al., 2004), areas with mine activities (Borden and Black, 2011; Montiel-Rozas et al., 2015), overgrazed grasslands (Newman et al., 2014), and urban and industrial areas (Walter and Calvo, 2009). New Zealand produces $~ 500,000 \mathrm{t}$ of dewatered biosolids per year. Some $60 \%$ of these biosolids are landfilled, $10 \%$ are discharged in oceans, and only $30 \%$ are applied to land (ANZBP, 2016), despite the NZ waste strategy that states

M.J. Gutiérrez-Ginés, B.H. Robinson, J. Esperschuetz, and R. McLenaghen, Dep. of Soil and Physical Sciences, Faculty of Agriculture and Life Sciences, Lincoln Univ., New Zealand; M.J. Gutiérrez-Ginés, current address: Institute of Environmental Science and Research, Christchurch Science Centre, 27 Creyke Rd., Christchurch 8041; E. Madejón, Instituto de Recursos Naturales y Agrobiología de Sevilla (IRNAS(SIC), Spain; J. Horswell, Institute of Environmental Science and Research, Porirua, New Zealand. Assigned to Associate Editor Tracy Punshon.

Abbreviations: DHA, dehydrogenase activity; ICP-OES, inductively coupled plasma optical emission spectroscopy; MARS, microwave-assisted reaction system; NZ, New Zealand; OM, organic matter; PCA, principal component analysis; S1, Soil 1 without biosolids; S1+B, Soil 1 with biosolids; S2, Soil 2 without biosolids; S2+B, Soil 2 with biosolids. 
that $95 \%$ of biosolids should be beneficially reused (Bradley, 2008). Historically, biosolids have been applied to pine plantations, where they accelerate growth at the expense of wood quality (Wang et al., 2004, 2013; Xue et al., 2015).

By definition, restoration involves putting back what was there previously as completely as possible (Bradshaw, 1984). This implies that native species are required for restoration. Several studies (Kelty, 2006; Chazdon, 2008; Funk et al., 2008; Bremer and Farley, 2010) have highlighted the importance of using a diverse range of native species to increase the invasion resistance (Funk et al., 2008), biodiversity (Bremer and Farley, 2010), and the productivity and heterogeneity in stratification of canopies and roots systems (Kelty, 2006). Chazdon (2008) reported that reclamation and planting with native species is generally the best way to recover biodiversity and ecosystem services in highly degraded lands.

Many regions in $\mathrm{NZ}$ are depauperate in native species. For example, just $0.5 \%$ of the Canterbury region is under native vegetation (Ecroyd and Brockerhoff, 2005). There is increasing interest in restoring degraded lands in NZ to native vegetation, which can have economic (Franklin et al., 2015) as well as environmental values (Meurk, 2008; Franklin et al., 2015). Potentially, NZ's degraded lands could be restored to native vegetation using biosolids (Dickinson et al., 2015). However, it is unclear whether NZ native species will respond positively to elevated concentrations of plant macronutrients and trace elements. There is a paucity of information on the nutrient requirements of NZ native species. Franklin et al. (2015) reported that Kunzea robusta de Lange \& Toelken (kānuka), Carex virgata Sol. ex Boott (swamp sedge), Cordyline australis (G. Forst.) Endl (cabbage tree), and Austroderia richardii (Endl.) N.P. Barker \& H.P. Linder (toetoe) responded positively to $\mathrm{N}$ (200 $\mathrm{kg} \mathrm{hm}^{-2}$ eq.), but Leptospermum scoparium J.R.Forst. \& G.Forst. (mānuka) did not. Dickinson et al. (2015) reported that biosolids improved the growth of Grisilinea littoralis Raoul (kāpuka) and Kunzea robusta, but not Dodonaea viscosa Jacq. (akeake).

The addition of biosolids may also result in increased uptake of trace elements, particularly $\mathrm{Zn}$ and Cd (Gartler et al., 2013). Whereas $\mathrm{Zn}$ is an essential element that is deficient in many environments, $\mathrm{Cd}$ is a nonessential element that may enter food chains and detrimentally affect ecosystems (Madejón et al., 2004). Dickinson et al. (2015) concluded that biosolids had a negligible effect on the trace element concentrations in the foliage of native plants, given the responses of five species in an acidic, low-OM silt that was formerly under pine forestry.

We hypothesize that the addition of biosolids to poor soils could have contrasting effects on NZ native plants, many of which are adapted to low-fertility soils. Given the results of Dickinson et al. (2015), we hypothesize that biosolids addition will not lead to excessive concentrations of trace elements in the leaves of $\mathrm{NZ}$ native species. We also expect an improvement in soil microbial activity (measured by dehydrogenase activity) in biosolids-amended soils.

We aimed to determine the growth and elemental concentration profiles of $11 \mathrm{NZ}$ native species in two distinct low-fertility soils. We sought to evaluate the performance of candidate species for the reforestation of degraded soils.

\section{Materials and Methods}

\section{Collection of Soils and Biosolids}

We selected two low-fertility soils, an Orthic Brown Soil (S1) (Hewitt, 2010) from a recently milled Pinus radiata D. Don. plantation in the former Eyrewell Forest, $26 \mathrm{~km}$ southeast of Oxford, Canterbury ( $\left.43^{\circ} 43^{\prime} 87.11^{\prime \prime} \mathrm{S}, 172^{\circ} 45^{\prime} 30.79^{\prime \prime} \mathrm{E}\right)$. The second soil (S2) was a sand under exotic legumes some $5 \mathrm{~km}$ north of Kaikōura, Canterbury ( $\left.42^{\circ} 21^{\prime} 37.7^{\prime \prime} \mathrm{S} 173^{\circ} 41^{\prime} 28.1^{\prime \prime} \mathrm{E}\right)$. Some $400 \mathrm{~kg}$ of each soil were collected by removing any surface vegetation and sampling from the top $40 \mathrm{~cm}$. The soils were homogenized and passed through a 20-mm sieve to remove stones while maintaining soil aggregates and structure. Subsamples of both soils were taken for chemical analyses (Table 1). Both soils have low concentrations of OM and plant nutrients. Soil 1 is acidic, whereas $S 2$ is slightly alkaline.

Biosolids were collected from a stockpile at the Kaikōura Regional Treatment Works at Kaikōura, Canterbury. Before stockpiling, the biosolids went through an initial treatment of sedimentation and anaerobic digestion in settlement ponds. The biosolids were collected from eight different locations across the pile and bulked. The biosolids (with a water content of 50\%) were homogenized and passed through a $20-\mathrm{mm}$ sieve. Table 1 shows the chemical properties of the biosolids.

\section{Selection of Plant Species}

The criteria for selecting the native plant species were: (i) hardy species able to grow in open areas, (ii) common in diverse environments and soil conditions, (iii) dry tolerant, and (iv) culturally or economically important (Metcalf, 1991; Salmon, 1991; Crowe, 1997; DOC, 2005). We selected Austroderia richardii, Cordyline australis, Phormium cookianum Le Jol., P. tenax J.R. Forst. \& G. Forst, Ozothamnus leptophyllus (G. Forst.) Breitw. \& J.M. Ward, Olearia paniculata (J.R. Forst. \& G. Forst.) Druce, Coprosma robusta, Coprosma acerosa A. Cunn., Veronica salicifolia G. Forst (syn. Hebe salicifolia (G. Forst.) Pennel), Pittosporum tenuifolium, and Myoporum laetum G. Forst. Table 2 shows the vernacular names of these plant species, the family, and the growth type. In Table 2, plant species are divided into monocots and dicots. We selected $Z$ ea mays $\mathrm{L}$. as a reference species because its response to biosolids addition is well documented.

\section{Experimental Setup}

Biosolids were manually mixed with soil in a proportion of $10 \%$ fresh weight ( $50 \%$ moisture, $\sim 90 \mathrm{Mg} \mathrm{hm}^{-2}$ fresh biosolids, $\sim 45 \mathrm{Mg} \mathrm{hm}^{-2}$ of dry biosolids). According to Walter and Calvo (2009), this is an optimal rate for biosolids addition in degraded soils. Pots were filled with $2.5 \mathrm{~kg}$ of soil or biosolids-amended soil. The 2.5 -L pots $(170 \times 155 \mathrm{~mm})$ had holes in the base. A mesh was set in the bottom to avoid losing soil while facilitating draining. Each plant species was grown in each soil without biosolids (S1 and S2) and each soil with 10\% (w/w) biosolids $(\mathrm{S} 1+\mathrm{B}, \mathrm{S} 2+\mathrm{B})$. Five replicates per treatment and plant species were established. In the case of $Z$. mays, six replicates per treatment were included. The 244 pots were placed in a randomized block design in the plant growth facilities at Lincoln University $\left(43^{\circ} 38^{\prime} 42^{\prime \prime} \mathrm{S}, 172^{\circ} 27^{\prime} 41^{\prime \prime} \mathrm{E}\right)$. The temperature in the greenhouse ranged between 9 and $20^{\circ} \mathrm{C}$ during night time (10:00 PM until 6:00 $\mathrm{AM}$ ) and between 14 and $28^{\circ} \mathrm{C}$ during the day time. 
New Zealand native species were acquired from Waiora Nursery (http://www.waioralandscapes.co.nz) and the Department of Conservation of NZ Nursery, Motukarara (http://www.doc.govt. nz/our-work/motukarara-conservation-nursery/). Plants had an average height of $15 \mathrm{~cm}$. Before planting, roots of plants were washed in tap water to remove as much of the original growth substrate as possible. Plants were watered daily to field (pot) capacity. When the soil in the pots was visually very dry between consecutive irrigation times, the plants were harvested. The growing times for each species were $Z$. mays: $4.5 \mathrm{wk}$; $M$. laetum and $H$. salicifolia: 9 wk; C. robusta and O. leptophyllus: 15 wk; $A$. richardii: 19 wk; $C$. australis, $C$. acerosa, $P$. tenuifolium, and $P$. tenax: $22 \mathrm{wk}$; $P$. cookianum: $6 \mathrm{mo}$; O. paniculata: $6.5 \mathrm{mo}$.

At the end of experiment, aboveground parts were cut, washed in tap water, rinsed with deionized water, and oven dried at $65^{\circ} \mathrm{C}$ for $1 \mathrm{wk}$. Leaves were separated from stems and stored for chemical analyses. In the case of $C$. acerosa, which produced fruits during the experiment, fruits were separated and sampled

Table 1. Mean and standard deviation $(n=5)$ of the parameters determined in soils, biosolids, and mixtures used in the bioassay.

\begin{tabular}{|c|c|c|c|c|c|c|}
\hline Parameter & Unit† & Soil 1 & Soil 2 & Biosolids & Soil 1 + biosolids & Soil $2+$ biosolids \\
\hline $\mathrm{pH}$ & & $4.9 \pm 0.0$ & $8.8 \pm 0.1$ & $4.3 \pm 0.0$ & $4.3 \pm 0.0$ & $5.2 \pm 0.1$ \\
\hline EC & $\mu \mathrm{S} \mathrm{cm}-1$ & $97 \pm 3.2$ & $24 \pm 1.3$ & $2634 \pm 52$ & $397 \pm 21$ & $282 \pm 25$ \\
\hline C & $\%$ & $3.9 \pm 0.2$ & $0.13 \pm 0.03$ & $23 \pm 1.5$ & $4.9 \pm 0.32$ & $0.33 \pm 0.03$ \\
\hline $\mathrm{N}$ & $\%$ & $0.20 \pm 0.01$ & $<0.050$ & $2.3 \pm 0.1$ & $0.97 \pm 0.24$ & $0.11 \pm 0.02$ \\
\hline $\mathrm{NH}_{4}^{+}-\mathrm{N}$ & & $3.1 \pm 0.5$ & $<0.100$ & $504 \pm 25$ & $18 \pm 2.5$ & $17 \pm 4.7$ \\
\hline $\mathrm{NO}_{3}^{-}-\mathrm{N}$ & & $23 \pm 3.4$ & $<0.100$ & $634 \pm 57$ & $87 \pm 26$ & $35 \pm 7.6$ \\
\hline \multirow[t]{2}{*}{ S } & $\mathrm{T}$ & $210 \pm 3.7$ & $110 \pm 13$ & $9010 \pm 200$ & $830 \pm 102$ & $550 \pm 47$ \\
\hline & E & $32 \pm 51$ & $32 \pm 50$ & $1500 \pm 200$ & $180 \pm 16$ & $150 \pm 20$ \\
\hline$P$ & $\mathrm{~T}$ & $370 \pm 6.9$ & $480 \pm 36$ & $5660 \pm 230$ & $690 \pm 66$ & $610 \pm 19$ \\
\hline Olsen P & & $42 \pm 1.2$ & $0.7 \pm 0.1$ & $270 \pm 5.6$ & $67 \pm 2.1$ & $47 \pm 3.3$ \\
\hline $\mathrm{Ca}$ & $\mathrm{T}\left(\mathrm{g} \mathrm{kg}^{-1}\right)$ & $2.7 \pm 0.08$ & $8.9 \pm 0.52$ & $11 \pm 0.32$ & $3.3 \pm 0.13$ & $8.1 \pm 0.25$ \\
\hline \multirow[t]{2}{*}{ K } & $\mathrm{T}\left(\mathrm{g} \mathrm{kg}^{-1}\right)$ & $4.7 \pm 0.06$ & $3.9 \pm 0.22$ & $3.8 \pm 0.05$ & $4.5 \pm 0.13$ & $4.1 \pm 0.17$ \\
\hline & E & $98 \pm 50$ & $150 \pm 110$ & $160 \pm 20$ & $99 \pm 10$ & $49 \pm 10$ \\
\hline \multirow[t]{2}{*}{$\mathrm{Mg}$} & $\mathrm{T}\left(\mathrm{g} \mathrm{kg}^{-1}\right)$ & $4.1 \pm 0.05$ & $6.4 \pm 0.17$ & $3.9 \pm 0.09$ & $4.4 \pm 0.10$ & $6.4 \pm 0.19$ \\
\hline & E & $140 \pm 40$ & $120 \pm 12$ & $230 \pm 13$ & $160 \pm 13$ & $82 \pm 13$ \\
\hline \multirow[t]{2}{*}{$\mathrm{Na}$} & $\mathrm{T}$ & $220 \pm 4.3$ & $240 \pm 12$ & $400 \pm 14$ & $240 \pm 11$ & $220 \pm 18$ \\
\hline & $E$ & $25 \pm 7.8$ & $41 \pm 4.3$ & $110 \pm 9.1$ & $49 \pm 4.9$ & $29 \pm 4.7$ \\
\hline \multirow[t]{2}{*}{$\mathrm{Mn}$} & $\mathrm{T}$ & $340 \pm 15$ & $430 \pm 11$ & $250 \pm 7.2$ & $350 \pm 13$ & $430 \pm 23$ \\
\hline & $E$ & $12 \pm 4$ & $0.3 \pm 0.0$ & $52 \pm 12$ & $37 \pm 2.8$ & $4.6 \pm 0.8$ \\
\hline \multirow[t]{2}{*}{$\mathrm{Zn}$} & $\mathrm{T}$ & $69 \pm 1.6$ & $50 \pm 1.1$ & $1240 \pm 45$ & $170 \pm 13$ & $120 \pm 6.5$ \\
\hline & $E$ & $0.4 \pm 0.2$ & $0.1 \pm 0.1$ & $280 \pm 54$ & $38 \pm 3.9$ & $20 \pm 4.7$ \\
\hline \multirow[t]{2}{*}{$\mathrm{Cu}$} & $\mathrm{T}$ & $3.0 \pm 0.2$ & $11 \pm 1.5$ & $610 \pm 16$ & $42 \pm 8.9$ & $43 \pm 4.0$ \\
\hline & $E$ & $0.04 \pm 0.06$ & $0.01 \pm 0.01$ & $3.0 \pm 2.2$ & $0.18 \pm 0.02$ & $0.15 \pm 0.04$ \\
\hline \multirow[t]{2}{*}{$\mathrm{Cd}$} & $\mathrm{T}$ & $0.01 \pm 0.01$ & $<0.003$ & $2.22 \pm 0.14$ & $0.23 \pm 0.10$ & $0.06 \pm 0.03$ \\
\hline & $E$ & $0.01 \pm 0.01$ & $<0.001$ & $0.57 \pm 0.35$ & $0.05 \pm 0.01$ & $0.03 \pm 0.01$ \\
\hline \multirow[t]{2}{*}{$\mathrm{Pb}$} & $\mathrm{T}$ & $15 \pm 0.8$ & $14 \pm 0.4$ & $120 \pm 4.3$ & $21 \pm 4.4$ & $17 \pm 0.5$ \\
\hline & $\mathrm{E}$ & $<0.020$ & $<0.020$ & $0.09 \pm 0.06$ & $<0.020$ & $<0.020$ \\
\hline
\end{tabular}

† Units are $\mathrm{mg} \mathrm{kg}^{-1}$ dry weight unless otherwise indicated. T, pseudototal concentration; E, extractable concentration.

Table 2. New Zealand native plant species used in the experiment. Names are checked by May 2016 in www.nzflora.info.

\begin{tabular}{|c|c|c|c|}
\hline Species & Family & Vernacular names & Growth characteristics \\
\hline \multicolumn{4}{|l|}{ Monocots } \\
\hline Austroderia richardii (Endl.) N.P. Barker \& H.P. Linder & Gramineae & Toetoe & Tussock (1 m), flower heads to $2-3 \mathrm{~m}$ \\
\hline Cordyline australis (G. Forst.) Endl & Asparagaceae & Cabbage tree & Tree $(5-12 \mathrm{~m})$ \\
\hline Phormium cookianum Le Jol. & Hemerocallidaceae & Mountain flax, wharariki & Tussock $(60 \mathrm{~cm})$, long flowers up to $1.5 \mathrm{~m}$ \\
\hline Phormium tenax J.R. Forst. \& G. Forst & Hemerocallidaceae & Flax, harareke & Tussock (2-3 m), flower stems up to $4-5 \mathrm{~m}$ tall \\
\hline \multicolumn{4}{|l|}{ Dicots } \\
\hline Coprosma robusta Raoul & Rubiaceae & Karamū & Fast-growing shrub $\sim 3 \mathrm{~m}$ tall \\
\hline Coprosma acerosa A. Cunn. & Rubiaceae & Sand coprosma, tarakupenga & Low-growing prostrate or trailing shrub \\
\hline Myoporum laetum G .Forst. & Scrophulariaceae & Ngaio & Shrub or small tree $(2.5-9 \mathrm{~m})$ \\
\hline Olearia paniculata (J.R. Forst. \& G. Forst.) Druce & Compositae & Akiraho, golden akeake & Bushy shrub or small tree $(2.5-6 \mathrm{~m})$ \\
\hline $\begin{array}{l}\text { Ozothamnus leptophyllus (G. Forst.) Breitw. \& } \\
\text { J.M. Ward }\end{array}$ & Compositae & Cottonwood, tauhinu & Many branched shrub (1.8 m) \\
\hline Pittosporum tenuifolium Sol. ex Gaertn. & Pittosporaceae & Black matipo, kōhūhū & Small tree $(4.6-9 \mathrm{~m})$ \\
\hline $\begin{array}{l}\text { Veronica salicifolia G. Forst [syn. Hebe salicifolia (G. } \\
\text { Forst.) Pennell†] }\end{array}$ & Plantaginaceae & Koromiko & Fast growing shrub (5 m) \\
\hline
\end{tabular}

† Since this species is mostly known as Hebe salicifolia, we will use this name in the text. 
individually. Root weight was not included in this study because, in general, root biomass is highly correlated with shoot biomass. Only when there is a severe nutrient deficiency do root:shoot ratios change significantly (Hodge, 2009). Root chemical analyses were not included for this study, and we prioritized leaf analysis. Leaves are commonly used to study the nutrient status of plants, as well as the risk of trace elements entering the trophic networks, and so it is easier to compare with other results in the literature.

Samples were weighed and ground and passed through a $500-\mu \mathrm{m}$ stainless-steel sieve. The rhizosphere soil (which is attached to the roots) was also collected to determine the dehydrogenase activity.

\section{Chemical Analysis}

Ammonia and nitrate concentration in soils, biosolids, and amended soils were determined in fresh samples, sieved through $2 \mathrm{~mm}$ at the beginning of the experiment. To determine $\mathrm{NH}_{4}^{+}$and $\mathrm{NO}_{3}^{-}$concentrations, samples were extracted with $\mathrm{KCl}$ (Clough et al., 2001) and analyzed with a Flow Injection Analyzer (FOSS FIAstar 5000). The samples of soil, biosolids, and amended soils were later dried at room temperature and analyzed for $\mathrm{pH}$ in 1:2.5 soil-water ratio, electrical conductivity, pseudo-total concentration of elements (acid digestion in the microwave [CEM MARS Xpress] according to the equipment specifications), exchangeable concentration of elements [extraction with $0.05 \mathrm{M} \mathrm{Ca}\left(\mathrm{NO}_{3}\right)_{2}$; McLaren et al., 2005] by inductively coupled plasma optical emission spectroscopy (ICP-OES, Varian 720-ES), Olsen P (Olsen et al., 1954), and total $\mathrm{C}$ and $\mathrm{N}$ concentration with an Elementar Vario-Max CN Elemental Analyzer. Dehydrogenase activity (DHA) was analyzed in the fresh rhizosphere soil following the method described by Alef (1995).

Plant material was analyzed for $\mathrm{N}$ and $\mathrm{C}$ using the $\mathrm{CN}$ Elemental analyzer. Mineral nutrients (P, $\mathrm{K}, \mathrm{Ca}, \mathrm{Mg}$, and $\mathrm{S}$ ) and trace elements ( $\mathrm{As}, \mathrm{Cd}, \mathrm{Cu}, \mathrm{Pb}$, and $\mathrm{Zn}$ ) were extracted by acid digestion the microwave CEM MARS Xpress according to the equipment specifications for plant extraction. Analysis of mineral nutrients and trace elements in the extracts of soil and plants were determined by the ICP-OES and expressed on a dry-weight basis.

The microwave extraction method was assessed using a reference soil (reference 981, sandy soil from the Netherlands) and a reference plant sample (reference 952, mixture of grasses from the Netherlands) from Wageningen Evaluating Programs for Analytical Laboratories (WEPAL, NL-6700 EC Wageningen, the Netherlands). We obtained recoveries between 85 and $120 \%$.

\section{Statistical Analysis}

Data of dry weight and element concentration in plants were compared in each species between the four treatments by ANOVA and post hoc multiple comparison testing (LSD test). When hypothesis of normality and homoscedasticity were not fulfilled, data were $\log$ transformed. Standardized data of dry weight and the foliar concentrations of $\mathrm{N}, \mathrm{S}, \mathrm{P}, \mathrm{Ca}, \mathrm{Mg}, \mathrm{Na}, \mathrm{K}$, $\mathrm{Mn}, \mathrm{Zn}, \mathrm{Cu}$, and $\mathrm{Cd}$ were analyzed using a principal component analysis (PCA). Averages of the PCA results in each species and treatment were calculated and represented in the figures. Statistics were performed using Statgraphics Centurion XVII.

\section{Results and Discussion}

\section{Plant Growth}

The growth of all plant species (measured as dry weight in the end of the experiment) increased in $\mathrm{S} 1$ amended with biosolids (Fig. 1). Compared with $\mathrm{S} 1$, the dry biomass increase in $\mathrm{S} 1+\mathrm{B}$ ranged from 25 (O. paniculata) to $95 \%$ (P. cookianum). None of the native species responded as well as $Z$. mays (500\% increase), which may reflect the high nutrient requirements of this crop plant (Bozkurt et al., 2006) compared with the native species, which generally grow on poorer soils (Wardle, 1991).

Given that the percentage increase in OM and nutrients was higher in S2 than S1 (Table 1) after biosolids addition, we would expect a greater plant growth response in this soil than in S1. In the case of $P$. tenuifolium, $M$. laetum, $C$. australis, $P$. tenax, $C$. robusta, and $O$. paniculata, as well as our reference species $Z$. mays, the percentage increase in biomass in the $\mathrm{S} 2+\mathrm{B}$ compared with the $S 2$ was significantly greater than the corresponding increase when biosolids were added to $S 1$. However, in contrast with our hypothesis, there was no significant increase in the biomass of $P$. cookianum, O. leptophyllus, C. acerosa, and H. salicifolia.

For these species, the dramatic $\mathrm{pH}$ decrease and salinity increase caused by the biosolids addition (Table 1) could have negatively counteracted the positive effect caused by the nutrient addition.

Whereas Dickinson et al. (2015) reported negligible biomass increases for native plants grown in biosolids-amended soil, our study showed that most species responded positively to biosolids addition, but that this response was soil dependent. In our experiment, the only species in common with those used by Dickinson et al. (2015) was $P$. tenax. In our study, $P$. tenax responded positively to biosolids in both $S 1$ and $S 2$, underlining the importance of soil type on the plant response to biosolids.

Many authors (Moreno-Peñaranda et al., 2004; Walter and Calvo, 2009) have shown that the plant communities established on degraded soils using biosolids are distinct from the communities that would spontaneously occur if biosolids were not added. The competition between species is also different when biosolids are added, and sometimes the better competitors in such remediated areas are not the desired species for the remediation (Borden and Black, 2011). In our study, the exotic $Z$. mays was the fastest growing plant in the $\mathrm{S} 1+\mathrm{B}$ and $\mathrm{S} 2+\mathrm{B}$ treatments. According to Borden and Black (2011), biosolids addition could increase the growth of exotic species, many of which are more adapted to high-fertility environments than the native species, which may lead to increased problems with weeds in sites restored using biosolids. Native species that usually show positive interactions (ecological facilitation) could become competitors when the nutrient status in soils is improved (Liu et al., 2013). These findings suggest that further research with assemblages of native plants in field conditions is needed to evaluate community dynamics in restoration with biosolids.

\section{Plant Nutrition}

Tables 3 and 4 show the elemental concentrations of plant leaves. The concentrations of $\mathrm{N}, \mathrm{S}$, and $\mathrm{P}$ in plant species were in most of the cases below the normal values for plants $(1-5$, $0.1-0.5$, and $0.3-0.5 \%$ for $\mathrm{N}, \mathrm{S}$, and $\mathrm{P}$ respectively) reported by Marschner (2012) when they grew in soils without amendment. However, these values increased significantly in all plant 

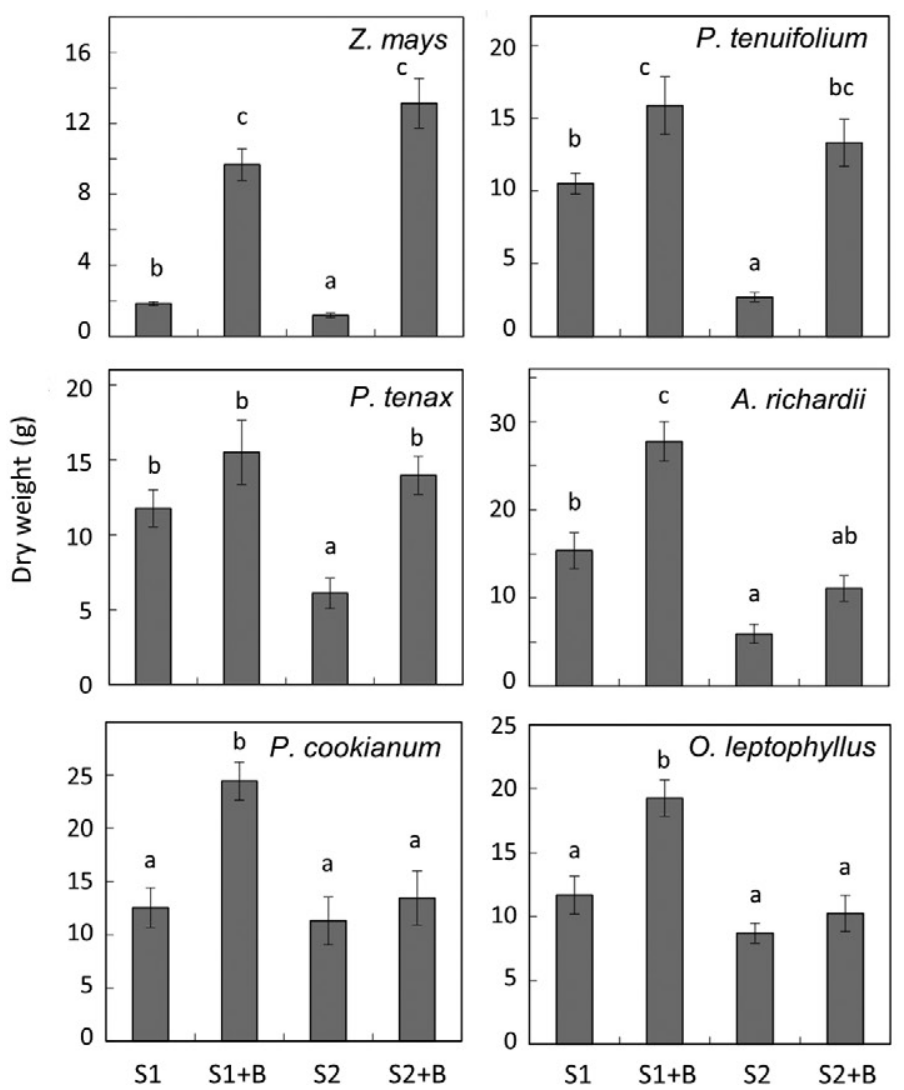
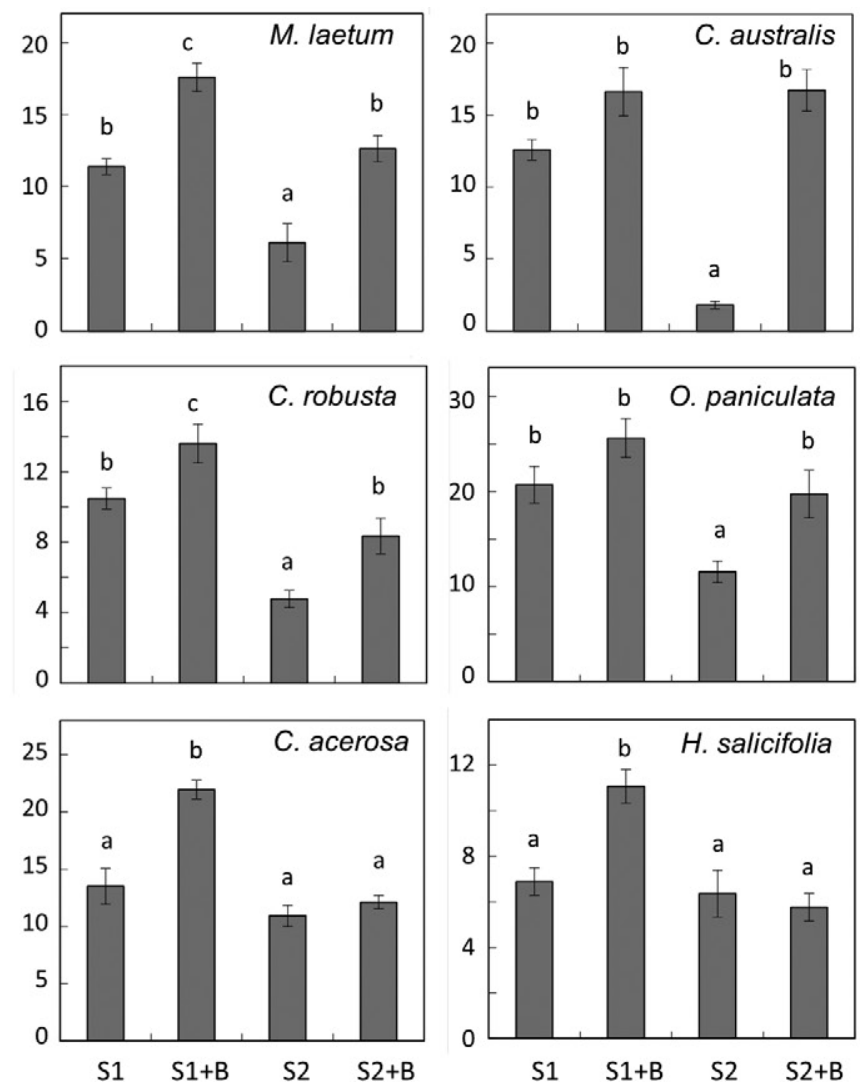

Fig. 1. Dry weight (g) of plants growing in Soils 1 and 2 without (S1 and S2) and with biosolids addition (S1+B and S2+B). Error bars indicate standard error $(n=5)$. Different letters indicate significant differences $(95 \%)$ between treatments.

Table 3. Nutrient and trace element concentration (average, $n=5$ ) in leaves of monocot species growing in soils with ( $\mathrm{S} 1+\mathrm{B}$ and $\mathrm{S} 2+\mathrm{B})$ and without (S1 and S2) biosolids. Different letters in each column of each species indicate significant differences at $95 \%$ of probability.

\begin{tabular}{|c|c|c|c|c|c|c|c|}
\hline Treatment & $\mathbf{N}$ & $\mathbf{S}$ & $\mathbf{P}$ & Mn & $\mathrm{Zn}$ & $\mathrm{Cu}$ & $\mathrm{Cd}$ \\
\hline & $\%$ & \multicolumn{2}{|c|}{$-\mathrm{g} \mathrm{kg}^{-1}-$} & \multicolumn{4}{|c|}{$\longrightarrow \mathrm{mg} \mathrm{kg}^{-1}$} \\
\hline \multicolumn{8}{|l|}{ Zea mays } \\
\hline S1 & $3.1 \mathrm{~d}$ & $1.6 \mathrm{c}$ & $1.1 \mathrm{~b}$ & $240 c$ & $50 \mathrm{~b}$ & $6.2 \mathrm{c}$ & $0.00 \mathrm{a}$ \\
\hline $\mathrm{S} 1+\mathrm{B}$ & $1.8 \mathrm{c}$ & $1.6 \mathrm{c}$ & $1.1 \mathrm{ab}$ & $230 c$ & $310 d$ & $5.0 \mathrm{~b}$ & $0.17 c$ \\
\hline S2 & $0.64 \mathrm{a}$ & $0.70 \mathrm{a}$ & $0.95 \mathrm{a}$ & $30 \mathrm{a}$ & $20 a$ & $3.7 \mathrm{a}$ & $0.00 \mathrm{a}$ \\
\hline $\mathrm{S} 2+\mathrm{B}$ & $1.1 \mathrm{~b}$ & $1.3 \mathrm{~b}$ & $1.1 \mathrm{ab}$ & $100 \mathrm{~b}$ & $150 c$ & $4.6 \mathrm{~b}$ & $0.10 \mathrm{~b}$ \\
\hline \multicolumn{8}{|c|}{ Austroderia richardii } \\
\hline S1 & $0.79 a$ & $0.97 a$ & $0.78 \mathrm{a}$ & $170 \mathrm{~b}$ & $10 \mathrm{a}$ & $2.3 \mathrm{a}$ & $0.00 \mathrm{a}$ \\
\hline $\mathrm{S} 1+\mathrm{B}$ & $0.59 a$ & $1.2 \mathrm{a}$ & $1.5 \mathrm{~b}$ & $280 \mathrm{c}$ & $140 \mathrm{~b}$ & $3.5 \mathrm{~b}$ & $0.11 \mathrm{~b}$ \\
\hline $\mathrm{S} 2$ & $0.75 \mathrm{a}$ & $1.3 \mathrm{a}$ & $0.90 \mathrm{a}$ & $30 a$ & $20 a$ & $2.8 \mathrm{ab}$ & $0.01 \mathrm{a}$ \\
\hline $\mathrm{S} 2+\mathrm{B}$ & $1.4 \mathrm{~b}$ & $2.0 \mathrm{~b}$ & $1.8 \mathrm{~b}$ & $50 \mathrm{a}$ & $160 \mathrm{~b}$ & $5.6 \mathrm{c}$ & $0.07 \mathrm{ab}$ \\
\hline \multicolumn{8}{|c|}{ Cordyline australis } \\
\hline S1 & $0.65 \mathrm{a}$ & $0.81 \mathrm{ab}$ & $1.2 \mathrm{a}$ & $390 \mathrm{c}$ & $40 \mathrm{a}$ & $5.6 \mathrm{ab}$ & $0.04 \mathrm{a}$ \\
\hline $\mathrm{S} 1+\mathrm{B}$ & $0.83 \mathrm{a}$ & $1.1 \mathrm{bc}$ & $1.9 \mathrm{bc}$ & $580 d$ & $340 c$ & $5.6 \mathrm{ab}$ & $1.03 \mathrm{c}$ \\
\hline $\mathrm{S} 2$ & $0.77 a$ & $1.1 \mathrm{a}$ & $1.8 \mathrm{ab}$ & $50 \mathrm{a}$ & $46 \mathrm{a}$ & $6.3 \mathrm{a}$ & $0.15 \mathrm{a}$ \\
\hline $\mathrm{S} 2+\mathrm{B}$ & $0.84 \mathrm{a}$ & $1.5 \mathrm{c}$ & $2.3 \mathrm{c}$ & $110 \mathrm{~b}$ & $250 \mathrm{~b}$ & $7.1 \mathrm{~b}$ & $0.69 \mathrm{~b}$ \\
\hline \multicolumn{8}{|c|}{ Phormium cookianum } \\
\hline S1 & $1.0 \mathrm{~b}$ & $0.86 \mathrm{ab}$ & $1.1 \mathrm{ab}$ & $160 \mathrm{~b}$ & $30 \mathrm{~b}$ & $2.6 \mathrm{ab}$ & $0.00 \mathrm{a}$ \\
\hline $\mathrm{S} 1+\mathrm{B}$ & $1.1 \mathrm{~b}$ & $1.0 \mathrm{~b}$ & $1.6 \mathrm{~b}$ & $300 c$ & $140 \mathrm{~d}$ & $4.2 \mathrm{c}$ & $0.62 b$ \\
\hline $\mathrm{S} 2$ & $0.53 \mathrm{a}$ & $0.52 \mathrm{a}$ & $0.92 \mathrm{a}$ & $80 \mathrm{a}$ & $20 \mathrm{a}$ & $1.1 \mathrm{a}$ & $0.00 \mathrm{a}$ \\
\hline $\mathrm{S} 2+\mathrm{B}$ & $1.1 \mathrm{~b}$ & $1.1 \mathrm{~b}$ & $1.4 \mathrm{ab}$ & $120 \mathrm{ab}$ & $40 c$ & $2.9 \mathrm{bc}$ & $0.15 \mathrm{a}$ \\
\hline \multicolumn{8}{|c|}{ Phormium tenax } \\
\hline S1 & $0.98 b$ & $0.82 \mathrm{a}$ & $1.3 \mathrm{~b}$ & $210 b$ & $40 \mathrm{a}$ & $2.7 \mathrm{~b}$ & $0.05 \mathrm{a}$ \\
\hline $\mathrm{S} 1+\mathrm{B}$ & $1.3 \mathrm{c}$ & $1.2 \mathrm{~b}$ & $2.0 \mathrm{c}$ & $330 c$ & $270 c$ & $4.6 \mathrm{c}$ & $0.65 \mathrm{~b}$ \\
\hline $\mathrm{S} 2$ & $0.55 \mathrm{a}$ & $0.58 \mathrm{a}$ & $0.84 a$ & $90 \mathrm{a}$ & $40 \mathrm{a}$ & $1.2 \mathrm{a}$ & $0.01 \mathrm{a}$ \\
\hline $\mathrm{S} 2+\mathrm{B}$ & $1.3 \mathrm{c}$ & $1.2 \mathrm{~b}$ & $2.3 \mathrm{c}$ & $90 \mathrm{a}$ & $110 \mathrm{~b}$ & $4.4 \mathrm{c}$ & $0.12 \mathrm{a}$ \\
\hline
\end{tabular}

species when biosolids were added to the two soil types, reaching values similar to those reported by Dickinson et al. (2015). Those authors studied the nutritional status of $11 \mathrm{NZ}$ native species grown in the same nursery where the plants of this study come from and others collected from two areas with different degrees of habitat alteration. Their results indicate that there are limiting nutrients in both soils, which are supplemented by biosolids addition. Nitrogen, $\mathrm{P}$, and $\mathrm{S}$ were significantly higher in the biosolids treatment (Table 1). The concentrations of these nutrients in $Z$. mays leaves were lower or similar in $\mathrm{S} 1+\mathrm{B}$ than in S1 (Table 3). This could be caused by a dilution effect, due to the small size of control plants. When the total uptake is calculated (data not shown), the $\mathrm{N}, \mathrm{P}$, and $\mathrm{S}$ mass extracted is significantly higher in $S 1+B$ than in $S 1$. In $S 2$, the concentration of these nutrients is higher with the application of biosolids. Even in biosolids-amended soils, the nutrient concentration does not reach the values reported by Bozkurt et al. (2006), who grew corn in up to $38 \mathrm{Mg} \mathrm{hm}^{-2}$ biosolids-amended soil. Nitrogen and P concentrations in biosolids used by Bozkurt et al. (2006) were similar to the concentrations of those nutrients in the biosolids that we used in our study.

Calcium, $\mathrm{K}, \mathrm{Mg}$, and $\mathrm{Na}$ concentrations in plants were dependent on species, soil type, and element (see the Supplemental Material for detailed results of chemical analysis). Concentrations of $\mathrm{Ca}, \mathrm{K}, \mathrm{Mg}$, and $\mathrm{Na}$ in both soils were unaffected by the addition of biosolids (Table 1); therefore, the changes in concentration of these elements is due more to general nutrient requirements and nutrient ratios of each species (Marschner, 2012) than to the addition of biosolids. 
Table 4. Nutrient and trace element concentration (average, $n=5$ ) in leaves of dicot species growing in soils with ( $\mathrm{S} 1+\mathrm{B}$ and $\mathrm{S} 2+\mathrm{B})$ and without (S1 and S2) biosolids. Different letters in each column of each species indicate significant differences at $95 \%$ of probability.

\begin{tabular}{|c|c|c|c|c|c|c|c|}
\hline Treatment & $\mathrm{N}$ & $S$ & $\mathbf{P}$ & $\mathrm{Mn}$ & $\mathrm{Zn}$ & $\mathrm{Cu}$ & $\mathrm{Cd}$ \\
\hline & $\%$ & \multicolumn{2}{|c|}{$-\mathrm{g} \mathrm{kg}^{-1}-$} & \multicolumn{4}{|c|}{$\mathrm{mg} \mathrm{kg}^{-1} \longrightarrow$} \\
\hline \multicolumn{8}{|c|}{ Coprosma acerosa leaves } \\
\hline S1 & $1.3 \mathrm{~b}$ & $1.4 \mathrm{~b}$ & $1.3 \mathrm{a}$ & $780 \mathrm{~b}$ & $80 a$ & $3.4 \mathrm{a}$ & $0.07 a$ \\
\hline $\mathrm{S} 1+\mathrm{B}$ & $1.6 \mathrm{c}$ & $2.6 \mathrm{c}$ & $2.0 \mathrm{~b}$ & $1120 \mathrm{c}$ & $430 c$ & $5.9 \mathrm{~b}$ & $1.53 \mathrm{~b}$ \\
\hline S2 & $0.84 a$ & $0.75 \mathrm{a}$ & $0.86 \mathrm{a}$ & $240 \mathrm{a}$ & $70 a$ & $1.7 \mathrm{a}$ & $0.05 \mathrm{a}$ \\
\hline $\mathrm{S} 2+\mathrm{B}$ & $1.6 \mathrm{C}$ & $2.4 \mathrm{c}$ & $1.7 \mathrm{~b}$ & $260 \mathrm{a}$ & $170 \mathrm{~b}$ & $5.3 \mathrm{~b}$ & $0.61 \mathrm{~b}$ \\
\hline \multicolumn{8}{|c|}{ Coprosma acerosa fruits } \\
\hline S1 & $1.2 \mathrm{a}$ & $1.1 \mathrm{a}$ & $2.0 \mathrm{a}$ & $190 \mathrm{c}$ & $50 \mathrm{a}$ & $4.9 \mathrm{a}$ & $0.07 a b$ \\
\hline $\mathrm{S} 1+\mathrm{B}$ & $1.4 \mathrm{a}$ & $1.3 \mathrm{~b}$ & $2.3 \mathrm{a}$ & $200 c$ & $110 c$ & $5.6 \mathrm{a}$ & $0.60 c$ \\
\hline S2 & $1.4 \mathrm{a}$ & $1.1 \mathrm{ab}$ & $2.2 \mathrm{a}$ & $50 \mathrm{a}$ & $50 a$ & $5.0 \mathrm{a}$ & $0.05 a$ \\
\hline$S 2+B$ & $1.4 \mathrm{a}$ & $1.7 c$ & $2.3 \mathrm{a}$ & $70 \mathrm{~b}$ & $60 \mathrm{~b}$ & $6.1 \mathrm{a}$ & $0.14 \mathrm{~b}$ \\
\hline \multicolumn{8}{|c|}{ Coprosma robusta } \\
\hline S1 & $1.3 b$ & $1.2 \mathrm{~b}$ & $0.99 a$ & $340 \mathrm{c}$ & $50 a$ & $2.4 \mathrm{a}$ & $0.06 a$ \\
\hline $\mathrm{S} 1+\mathrm{B}$ & $1.7 \mathrm{c}$ & $2.2 \mathrm{~d}$ & $1.8 \mathrm{c}$ & $590 \mathrm{~d}$ & $490 \mathrm{c}$ & $6.3 c$ & $1.63 c$ \\
\hline S2 & $0.88 \mathrm{a}$ & $0.93 \mathrm{a}$ & $0.91 \mathrm{a}$ & $80 a$ & $40 \mathrm{a}$ & $1.9 \mathrm{a}$ & $0.17 a b$ \\
\hline $\mathrm{S} 2+\mathrm{B}$ & $1.3 \mathrm{~b}$ & $1.61 \mathrm{c}$ & $1.4 \mathrm{~b}$ & $160 \mathrm{~b}$ & $140 \mathrm{~b}$ & $4.7 \mathrm{~b}$ & $0.36 \mathrm{~b}$ \\
\hline \multicolumn{8}{|c|}{ Myoporum laetum } \\
\hline S1 & $1.0 \mathrm{~b}$ & $2.2 \mathrm{a}$ & $0.90 \mathrm{a}$ & $160 \mathrm{~b}$ & $20 \mathrm{a}$ & $4.6 \mathrm{a}$ & $0.00 \mathrm{a}$ \\
\hline $\mathrm{S} 1+\mathrm{B}$ & $1.4 \mathrm{~d}$ & $3.6 \mathrm{~b}$ & $1.8 \mathrm{~b}$ & $310 c$ & $370 c$ & $16 \mathrm{~b}$ & $0.34 \mathrm{~b}$ \\
\hline S2 & $0.75 \mathrm{a}$ & $2.4 \mathrm{a}$ & $0.96 a$ & $80 a$ & $30 \mathrm{a}$ & $4.0 \mathrm{a}$ & $0.01 \mathrm{a}$ \\
\hline $\mathrm{S} 2+\mathrm{B}$ & $1.2 \mathrm{c}$ & $4.1 \mathrm{~b}$ & $1.9 \mathrm{~b}$ & $130 \mathrm{~b}$ & $130 \mathrm{~b}$ & $15.1 \mathrm{~b}$ & $0.20 \mathrm{~b}$ \\
\hline \multicolumn{8}{|c|}{ Olearia paniculata } \\
\hline S1 & $0.79 \mathrm{~b}$ & $0.59 \mathrm{~b}$ & $0.87 a$ & $140 \mathrm{~b}$ & $20 \mathrm{a}$ & $3.0 \mathrm{~b}$ & $0.01 \mathrm{a}$ \\
\hline $\mathrm{S} 1+\mathrm{B}$ & $1.1 \mathrm{c}$ & $0.96 c$ & $1.2 \mathrm{bc}$ & $280 \mathrm{c}$ & $280 \mathrm{c}$ & $11 \mathrm{c}$ & $0.44 \mathrm{~b}$ \\
\hline S2 & $0.49 a$ & $0.40 \mathrm{a}$ & $0.92 \mathrm{ab}$ & b $60 a$ & $20 a$ & $1.5 \mathrm{a}$ & $0.08 \mathrm{a}$ \\
\hline $\mathrm{S} 2+\mathrm{B}$ & $1.2 \mathrm{C}$ & $1.0 \mathrm{c}$ & $1.3 \mathrm{c}$ & $60 a$ & $70 \mathrm{~b}$ & $8.5 c$ & $0.09 a$ \\
\hline \multicolumn{8}{|c|}{ Ozothamnus leptophyllus } \\
\hline S1 & $1.3 \mathrm{~b}$ & $1.2 \mathrm{~b}$ & $1.3 \mathrm{a}$ & $390 \mathrm{~b}$ & $40 \mathrm{a}$ & $4.2 \mathrm{a}$ & $0.04 \mathrm{a}$ \\
\hline $\mathrm{S} 1+\mathrm{B}$ & $1.5 \mathrm{~b}$ & $1.9 c$ & $2.5 \mathrm{~b}$ & $790 \mathrm{c}$ & $320 c$ & $12.5 \mathrm{~b}$ & $0.53 c$ \\
\hline S2 & $0.68 \mathrm{a}$ & $0.64 \mathrm{a}$ & $1.2 \mathrm{a}$ & $190 \mathrm{a}$ & $30 \mathrm{a}$ & $2.0 \mathrm{a}$ & $0.06 \mathrm{a}$ \\
\hline $\mathrm{S} 2+\mathrm{B}$ & $1.2 \mathrm{~b}$ & $2.8 d$ & $1.5 \mathrm{a}$ & $260 \mathrm{ab}$ & $90 \mathrm{~b}$ & $5.4 \mathrm{a}$ & $0.18 \mathrm{~b}$ \\
\hline \multicolumn{8}{|c|}{ Pittosporum tenuifolium } \\
\hline S1 & $0.92 \mathrm{~b}$ & $0.98 \mathrm{a}$ & $1.1 \mathrm{~b}$ & $890 \mathrm{c}$ & $70 b$ & $3.0 \mathrm{~b}$ & $0.05 \mathrm{a}$ \\
\hline $\mathrm{S} 1+\mathrm{B}$ & $1.0 \mathrm{~b}$ & $1.3 \mathrm{~b}$ & $1.9 c$ & $780 \mathrm{c}$ & $1010 d$ & $4.2 \mathrm{c}$ & $2.15 c$ \\
\hline S2 & $0.55 \mathrm{a}$ & $0.86 \mathrm{a}$ & $0.72 \mathrm{a}$ & $50 \mathrm{a}$ & $30 \mathrm{a}$ & $1.0 \mathrm{a}$ & $0.00 \mathrm{a}$ \\
\hline $\mathrm{S} 2+\mathrm{B}$ & $1.4 \mathrm{c}$ & $1.5 \mathrm{c}$ & $1.9 c$ & $180 \mathrm{~b}$ & $610 c$ & $5.4 \mathrm{~d}$ & $0.82 \mathrm{~b}$ \\
\hline \multicolumn{8}{|c|}{ Hebe salicifolia } \\
\hline S1 & $1.3 b$ & $1.5 \mathrm{a}$ & $1.1 \mathrm{a}$ & $210 a$ & $10 a$ & $1.5 \mathrm{~b}$ & $0.00 \mathrm{a}$ \\
\hline $\mathrm{S} 1+\mathrm{B}$ & $1.8 \mathrm{c}$ & $3.2 \mathrm{c}$ & $2.0 \mathrm{~b}$ & $460 \mathrm{~b}$ & $280 c$ & $7.8 \mathrm{~d}$ & $1.12 \mathrm{c}$ \\
\hline S2 & $0.67 a$ & $1.1 \mathrm{a}$ & $1.2 \mathrm{a}$ & $180 \mathrm{a}$ & $10 a$ & $0.8 \mathrm{a}$ & $0.00 \mathrm{a}$ \\
\hline $\mathrm{S} 2+\mathrm{B}$ & $1.5 \mathrm{bc}$ & $2.3 \mathrm{~b}$ & $2.1 \mathrm{~b}$ & $210 a$ & $80 \mathrm{~b}$ & $4.9 c$ & $0.37 \mathrm{~b}$ \\
\hline
\end{tabular}

\section{Trace Elements}

The $\mathrm{Cu}$ concentrations in leaves of $C$. robusta, $C$. acerosa, P. tenuifolium, P. tenax, P. cookianum, O. paniculata, and $H$. salicifolia growing in $S 1$ and $S 2$ were $<2 \mathrm{mg} \mathrm{kg}^{-1}$, which is the $\mathrm{Cu}$ concentration required by most plants for normal growth (Marschner, 2012). Concentrations increased to the normal levels reported by Marschner (2012) and Dickinson et al. (2015) in the $\mathrm{S} 1+\mathrm{B}$ and $\mathrm{S} 2+\mathrm{B}$. Only $O$. paniculata grown in biosolidsamended soils had higher $\mathrm{Cu}$ concentration than in natural habitats (Dickinson et al., 2015). These concentration increases are consistent with the increase in extractable $\mathrm{Cu}$ in the biosolidsamended soils (Table 1).
In all cases, plants in the biosolids treatment had significantly higher foliar $\mathrm{Zn}$ concentrations than the controls. As with $\mathrm{Cu}$, this increase in foliar $\mathrm{Zn}$ follows an increase in the extractable $\mathrm{Zn}$ in soil (Table 1). The $\mathrm{Zn}$ concentrations in $O$. paniculata, $A$. richardii, $M$. laetum, $P$. cookianum, and $H$. salicifolia growing in nonamended soils were $<20 \mathrm{mg} \mathrm{kg}^{-1}$, a range considered by Marschner (2012) to be deficient. However, in the biosolids treatments, the $\mathrm{Zn}$ concentration increased to levels higher than those found for the same species in nursery and natural habitats (Dickinson et al., 2015), even levels that may be toxic for plants (>100 $\mathrm{mg} \mathrm{kg}^{-1}$; Chaney, 1989) or for livestock (>300 $\mathrm{mg} \mathrm{kg}^{-1}$; Chaney, 1989).

Although biosolids slightly increased Cd total and extractable concentration in soils (Table 1), many of the plant species in our experiment accumulated this element at high rates. This concentration did not reach toxic levels for plants $\left(>5 \mathrm{mg} \mathrm{kg}^{-1}\right.$; Chaney, 1989 ) in any species. However, P. tenuifolium, C. robusta, P. cookianum, $O$. leptophyllus, and $C$. acerosa in leaves and fruits and $H$. salicifolia, $C$. australis, and $P$. tenax growing in biosolids-amended soil reached $\mathrm{Cd}$ concentrations that exceeded the safe levels for livestock (0.5 mg kg-1 Chaney, 1989). In accordance with Hahner et al. (2014) and Dickinson et al. (2015), P. tenuifolium and $C$. robusta are the species with the highest $\mathrm{Cd}$ concentration in leaves.

Although Mn total concentration in biosolids-amended soils was similar to that in nonamended soils, the exchangeable fraction increased by biosolids addition (Table 1). The Mn concentration was higher in aerial parts of most of the species growing in biosolids-amended soils. Six species grown in $\mathrm{S} 1+\mathrm{B}$ reach values that could be considered phytotoxic ( $>400 \mathrm{mg} \mathrm{kg}^{-1}$; Chaney, 1989). Coprosma acerosa even could be a problem for livestock.

The behavior of $Z$. mays regarding trace element concentration was not very different from that of the native species. The $\mathrm{Cu}$ concentration was in the normal range for plants, according to Marschner (2012), and similar to the values reported by other authors who grew corn in biosolids-amended soils (Granato et al., 2004). The Mn was higher in the treatments with biosolids, but values did not reach the toxic levels for plants or livestock. Zinc and $\mathrm{Cd}$ concentrations increased significantly in the treatments with biosolids in both soils. The Cd concentration of $0.2 \mathrm{mg} \mathrm{kg}^{-1}$ is lower than that considered to be toxic for plants $\left(>5 \mathrm{mg} \mathrm{kg}^{-1}\right.$; Chaney, 1989) or livestock (0.5 $\mathrm{mg} \mathrm{kg}^{-1}$; Chaney, 1989). However, $\mathrm{Zn}$ in $\mathrm{S} 1+\mathrm{B}\left(310 \mathrm{mg} \mathrm{kg}^{-1}\right)$ may be toxic for plants $\left(>100 \mathrm{mg} \mathrm{kg}^{-1}\right.$; Chaney, 1989) or livestock (>300 $\mathrm{mg} \mathrm{kg}^{-1}$; Chaney, 1989).

However, plants did not show toxicity symptoms. Other authors have not reported signs of toxicity when corn accumulated high $\mathrm{Zn}$ concentrations due to biosolids addition (JarauschWehrheim et al., 1999; Granato et al., 2004), even at higher rates than the one we chose for this experiment.

Trace element concentration in the shoots can limit the use of these plants amended with high doses of biosolids for restoration of degraded areas. In this experiment, biosolids acidified the soil (especially S2), thereby increasing the solubility of cations. Biosolids also added OM, which can reduce cation mobility. These two effects are element dependent. However, other studies (Madejón et al., 2006; Ciadamidaro et al., 2015) have shown that Cd uptake in the field in biosolids-amended soil is often lower than in pot trials.

\section{Principal Component Analysis}

The general response of plants to biosolids addition in both soils was investigated by a PCA, which included the dry weight 
and elemental composition of all NZ-native plant species (Fig. 2). Zea mays was omitted from the analysis because there was a large difference in its response to biosolids, which masked differences between the native species. The first component separated the points without biosolids from those with biosolids addition. The variables with the highest weight in this component were $\mathrm{Zn}$, $\mathrm{Cd}, \mathrm{Mn}, \mathrm{P}, \mathrm{N}$, and $\mathrm{Cu}$, followed by $\mathrm{S}, \mathrm{Ca}$, and $\mathrm{Mg}$. The second component differentiated the points depending on the $\mathrm{Na}$ concentration, followed by the $\mathrm{K}, \mathrm{S}$, and $\mathrm{Cu}$ concentrations in the positive part of the axis, and the $\mathrm{Mn}, \mathrm{Cd}$, and $\mathrm{Zn}$ concentrations in the negative part of the axis. This second component was more related to differences in species behavior than biosolids addition. Although salinity of biosolids was high and they produce and increase in soil salinity when added (Table 1), the Na concentration in plants did not change with biosolids addition. Dry weight of plants was a low-weight variable in both components.

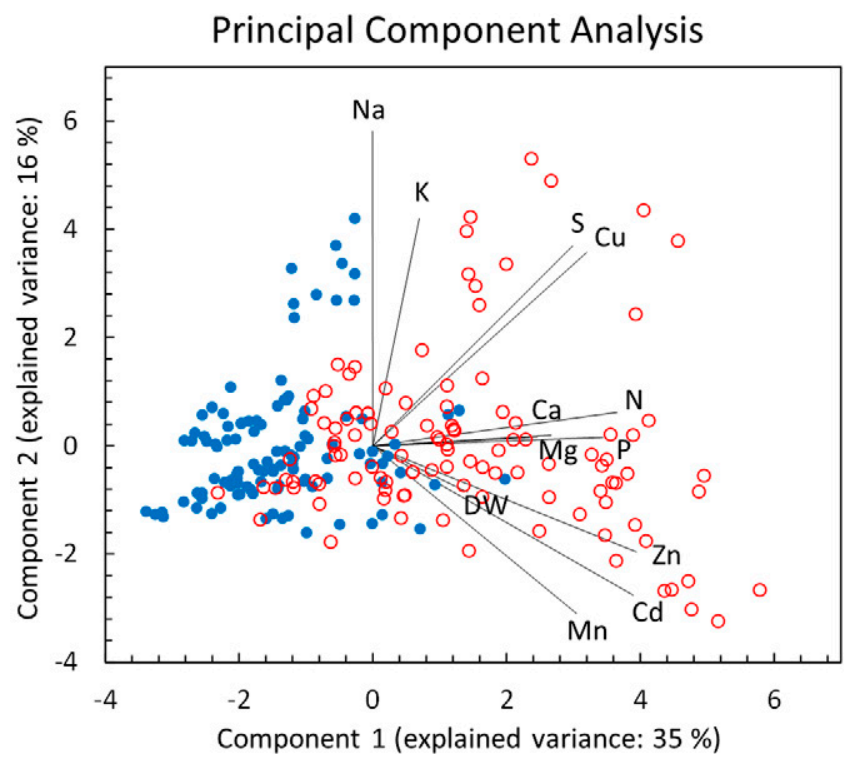

Fig. 2. Weight of the variables in the principal component analysis and scatterplot with the results of plant species in control soils in blue and biosolids-amended soils in red.
The behavior of plant species is represented according to their average PCA values in both soils (Fig. 3). Each arrow represents a single species. The arrows indicate the change from the average PCA value in the treatment without biosolids to the average PCA value in the treatment with biosolids. The PCA shows that all species in both soils significantly increase in Component 1 when biosolids were added to soils. This indicates that all species increase their concentration of macronutrients such as $\mathrm{N}, \mathrm{P}$, and $\mathrm{S}$ and trace elements $\mathrm{Mn}, \mathrm{Zn}, \mathrm{Cd}$, and $\mathrm{Cu}$ when biosolids were added, even those species that did not show great differences in biomass production due to the biosolids addition in S2. In accordance with Hahner et al. (2014), the native monocots show a pattern of lower concentration of nutrients than the dicots in S1 (Fig. 3). This difference was more pronounced in plants growing in biosolids-amended soil and was consistent with a higher nutrient requirement in dicots. If this is the case, then dicots may outperform monocots in native plant communities that are amended with biosolids.

The contrasting behavior of the species in each soil is shown in Component 2 (Fig. 3). This component separates species depending on their $\mathrm{Na}$ and $\mathrm{K}$ concentration (e.g., M. laetum, which was the species with the highest concentration of those nutrients). It also separates species depending on their response to biosolids addition, according to the relationship between $\mathrm{Mn}$, $\mathrm{Zn}$, and $\mathrm{Cd}$ increase and $\mathrm{S}$ and $\mathrm{Cu}$ increase. Figure 3 shows that the response of plants to biosolids addition was more species dependent in S2 than in S1.

The species with the highest differences in Component 2 in $S 1$ compared with $S 1+\mathrm{B}$ are $P$. tenuifolium, C. robusta, C. acerosa, and $C$. australis, followed by $A$. richardii and $P$. cookianum. In S2, C. robusta, P. tenuifolium, and Cordyline australis are more related to the negative part of Axis 2, meaning higher increase in dry weight and $\mathrm{Mn}, \mathrm{Zn}$, and $\mathrm{Cd}$ concentrations. The rest of species present an increase in Component 2 values in $\mathrm{S} 2+\mathrm{B}$ compared with $\mathrm{S} 2$, meaning higher $\mathrm{Cu}, \mathrm{K}$, and $\mathrm{S}$ concentrations compared with trace elements. This indicates which species concentrate the elements $\mathrm{Mn}, \mathrm{Zn}$, and $\mathrm{Cd}$ when biosolids are added in each soil type.
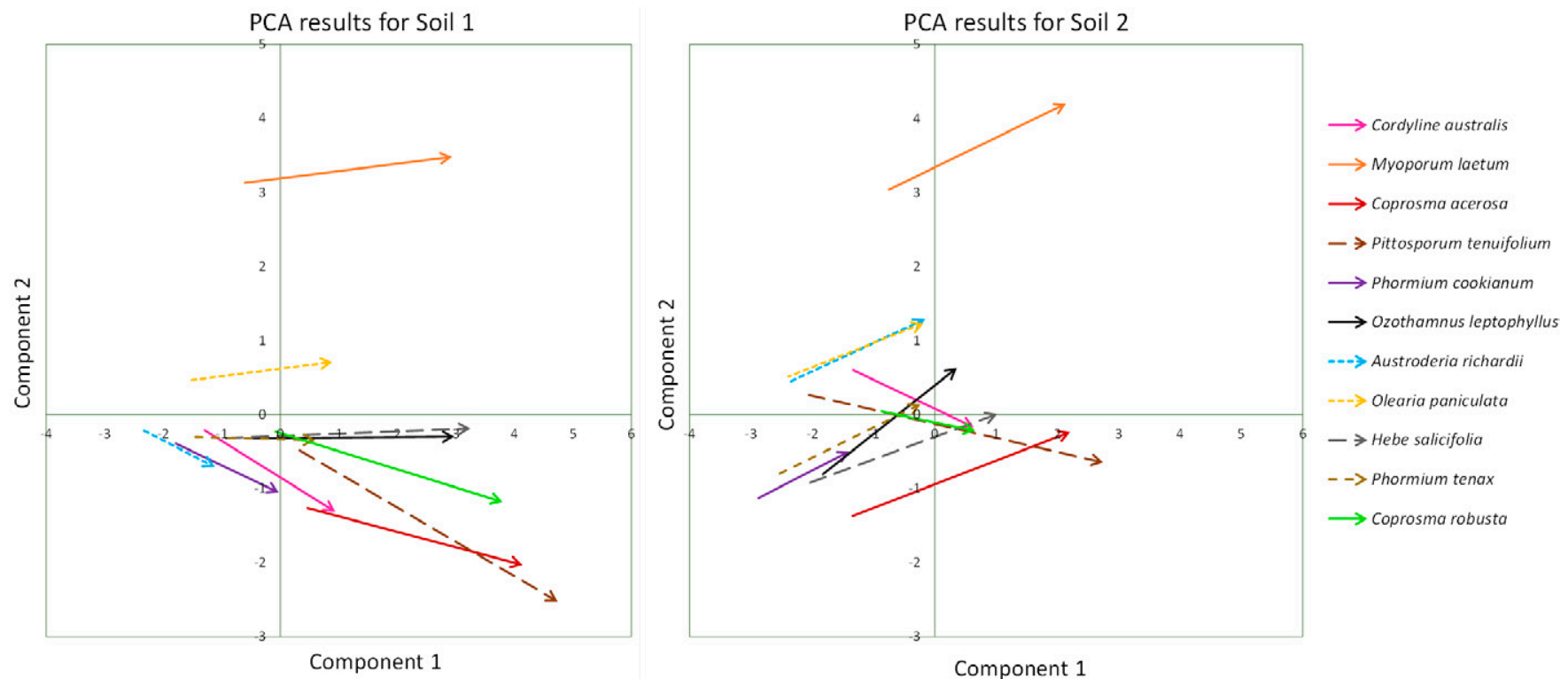

Fig. 3. Average response of plant species to biosolids addition in the two different soil types. Arrows indicate the change of the principal component analysis (PCA) average of the species in control soil (beginning of the arrow) to the PCA average in biosolids-amended soil (end of the arrow). 

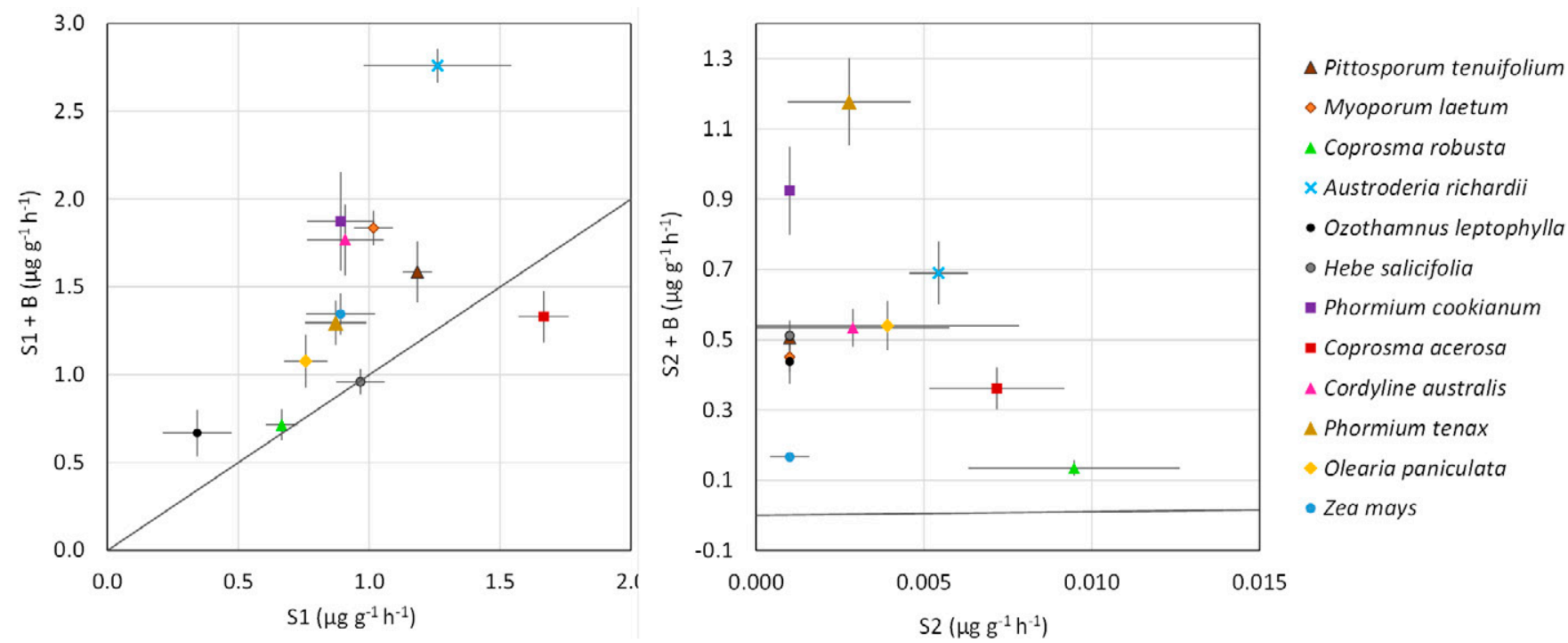

Fig. 4. Dehydrogenase activity $\left(\mu \mathrm{g} \mathrm{g}^{-1} \mathrm{~h}^{-1}\right)$ in Soil 1 (S1) compared with Soil 1 amended with biosolids (S1+B) in each species rhizosphere (left) and comparison of dehydrogenase activity in both soil types amended with biosolids (right).

\section{Dehydrogenase Activity}

Dehydrogenase activity is frequently used as a general measure of viable microorganisms in degraded soils (Gil-Sotres et al., 2005). Figure 4 shows the effect of the biosolids on values of DHA in the rhizospheres of the different species in both soils. In S1, biosolids improved microbial activity in the rhizosphere of all the species (except for $C$. acerosa). In $S 2$, the activity in the rhizosphere of all the species without amendment was almost null (Fig. 4), demonstrating the poor microbiological state of the original soil. Biosolids addition to this soil increased DHA to levels approaching S1. Many authors have shown the positive effect of biosolids on this activity in degraded soils (Pérez de Mora et al., 2005). Trace elements in the biosolids may be toxic to the soil biota (Obbard, 2001) and thereby offset the positive effects of the root system and OM addition (Pérez de Mora et al., 2005).

\section{Conclusions}

All NZ-native species tested benefited, in either growth or nutrient status, from biosolids addition to low-fertility soil. The growth responses were soil dependent, with 4 of the 11 species showing no increased growth rate in one of the biosolidsamended soils. The addition of biosolids into degraded soil could improve and accelerate the growth and establishment of the native plants tested. In the cases of $P$. tenuifolium and $C$. australis, the use of biosolids (or other fertilizer) would be a basic requirement if these species were to be planted in very low-fertility soils. Although most native species showed a positive response to biosolids, the response of $Z$. mays, a nutrient-demanding crop plant, was much greater. Using biosolids for ecological restoration may exacerbate problems with exotic weeds or even change relationships between native species. Field trials are required to investigate this, as well as the long-term consequences of applying biosolids to NZ-native vegetation. In particular, the concentrations of $\mathrm{Cd}$ in certain species (P. tenuifolium and C. robusta) should be monitored because these species may facilitate the entry of this toxic element into the food chain. In the case of using the biosolids described in this research, lower rates of application would be desired to decrease the risk of accumulating trace elements in leaves of native plants.

\section{Acknowledgments}

We gratefully acknowledge the Centre for Integrated Biowaste Research for funding of this study. Dr. MJ Gutiérrez-Ginés held a fellowship granted by Fundación Ramón Areces. Dr. E. Madejón thanks the financial support for her work at Lincoln University, New Zealand, from Program Salvador de Madariaga of the Spanish MECD.

\section{References}

Alef, K. 1995. Dehydrogenase activity. In: K. Alef and P. Nannipieri, editors, Methods in applied soil microbiology and biochemistry. Academic Press, London. p. 228-231.

ANZBP. 2016. New Zealand biosolids statistics. Aust. and N. Z. Biosolids Partnership, Aust. Water Assoc. http://www.biosolids.com.au/bs-nz.php (accessed 1 July 2016).

Borden, R.K., and R. Black. 2011. Biosolids application and long-term noxious weed dominance in the western United States. Restor. Ecol. 19:639-647. doi:10.1111/j.1526-100X.2010.00671.x

Bozkurt, M.A., H. Akdeniz, B. Keskin, and I.H. Yilmaz. 2006. Possibilities of using sewage sludge as nitrogen fertilizer for maize. Acta Agric. Scand., Sect. B 56:143-149. doi:10.1080/0906471051003113

Bradley, J. 2008. New Zealand. In: R.J. LeBlanc, P. Matthews, and R.P. Richard, editors, Global atlas of excreta, wastewater sludge, and biosolids management: Moving forward the sustainable and welcome uses of a global resource. UN Human Settlements Prog., UN-HABITAT, Nairobi, Kenya. p. 447-454.

Bradshaw, A.D. 1984. Ecological principles and land reclamation practice. Landscape Planning 11:35-48. doi:10.1016/0304-3924(84)90016-9

Bremer, L.L., and K.A. Farley. 2010. Does plantation forestry restore biodiversity or create green deserts? A synthesis of the effects of land-use transitions on plant species richness. Biodivers. Conserv. 19:3893-3915. doi:10.1007/ s10531-010-9936-4

Chaney, R.L. 1989. Toxic element accumulation in soils and crops: Protecting soil fertility and agricultural food-chains. In: B. Bar-Yosef, N.J. Barrow, and J. Goldshmid, editors, Inorganic contaminants in the vadose zone. Springer-Verlag, Berlin. p. 140-158. doi:10.1007/978-3-642-74451-8_10

Chazdon, R.L. 2008. Beyond deforestation: Restoring forests and ecosystem services on degraded lands. Science 320:1458-1460. doi:10.1126/science.1155365

Ciadamidaro, L., M. Puschenreiter, J. Santner, W.W. Wenzel, P. Madejón, and E. Madejón. 2015. Assessment of trace element phytoavailability in compost amended soils using different methodologies. J. Soils Sediments 17:1251261. doi: 10.1007/s11368-015-1283-3

Clough, T.J., R.J. Stevens, R.J. Laughlin, R.R. Sherlock, and K.C. Cameron. 2001. Transformations of inorganic-N in soil leachate under differing storage conditions. Soil Biol. Biochem. 33:1473-1480. doi:10.1016/ S0038-0717(01)00056-6 
Crowe, A. 1997. A field guide to the native edible plants of New Zealand. Godwit Publishing, Auckland, New Zealand.

Dickinson, N., M. Marmiroli, B. Das, D. McLaughlin, D. Leung, and B. Robinson. 2015. Endemic plants as browse crops in agricultural landscapes of New Zealand. Agroecol. Sustain. Food Syst. 39:224-242. doi:10.1080/21 683565.2014 .967438

DOC. 2005. Native plant communities of the Canterbury Plains. Dep. of Conservation, Christchurch, New Zealand.

Ecroyd, C.E., and E.G. Brockerhoff. 2005. Floristic changes over 30 years in a Canterbury Plains kānuka forest remnant, and comparison with adjacent vegetation types. N. Z. J. Ecol. 29:279-290.

Franklin, H.M., N.M. Dickinson, C.J.D. Esnault, and B.H. Robinson. 2015. Native plants and nitrogen in agricultural landscapes of New Zealand. Plant Soil 394:407-420. doi:10.1007/s11104-015-2622-2

Funk, J.L., E.E. Cleland, K.N. Suding, and E.S. Zavaleta. 2008. Restoration through reassembly: Plant traits and invasion resistance. Trends Ecol. Evol. 23:695-703. doi:10.1016/j.tree.2008.07.013

Gartler, J., B. Robinson, K. Burton, and L. Clucas. 2013. Carbonaceous soil amendments to biofortify crop plants with zinc. Sci. Total Environ. 465:308-313. doi:10.1016/j.scitotenv.2012.10.027

Gibbs, H.K., and J.M. Salmon. 2015. Mapping the world's degraded lands. Appl. Geogr. 57:12-21. doi:10.1016/j.apgeog.2014.11.024.

Gil-Sotres, F., C. Trasar-Cepeda, M.C. Leirós, and S. Seoane. 2005. Different approaches to evaluating soil quality using biochemical properties. Soil Biol. Biochem. 37:877-887. doi:10.1016/j.soilbio.2004.10.003

Granato, T.C., R.I. Pietz, G.J. Knafl, C.R. Carlson, P. Tata, and C. Lue-Hing. 2004. Trace element concentrations in soil, corn leaves, and grain after cessation of biosolids applications. J. Environ. Qual. 33:2078-2089. doi:10.2134/jeq2004.2078

Hahner, J.L., B.H. Robinson, Z. Hong-Tao, and N.M. Dickinson. 2014. The phytoremediation potential of native plants on New Zealand dairy farms. Int. J. Phytorem. 16:719-734. doi:10.1080/15226514.2013.856845

Hewitt, A.E. 2010. New Zealand soil classification. 3rd ed. Manaaki Whenua Press, Lincoln, New Zealand.

Hodge, A. 2009. Root decisions. Plant Cell Environ. 32:628-640. doi:10.1111/j.1365-3040.2008.01891.x

James, J., and R. Harrison. 2016. The effect of harvest on forest soil carbon: A meta-analysis. Forests 7:308. doi:10.3390/f7120308

Jarausch-Wehrheim, B., B. Mocquot, and M. Mench. 1999. Absorption and translocation of sludge-borne zinc in field-grown maize (Zea mays L.). Eur. J. Agron. 11:23-33. doi:10.1016/S1161-0301(99)00016-7

Jurgensen, M.F., A.E. Harvey, R.T. Graham, D.S. Page-Dumroese, J.R. Tonn, M.J. Larsen, and T.B. Jain. 1997. Impacts of timber harvesting on soil organic matter, nitrogen, productivity, and health of Inland Northwest forests. For. Sci. 43:234-251.

Kelty, M.J. 2006. The role of species mixtures in plantation forestry. For. Ecol. Manage. 233:195-204. doi:10.1016/j.foreco.2006.05.011

Liu, N., H. Ren, S. Yuan, Q. Guo, and L. Yang. 2013. Testing the stress-gradient hypothesis during the restoration of tropical degraded land using the shrub rhodomyrtus tomentosa as a nurse plant. Restor. Ecol. 21:578-584. doi:10.1111/j.1526-100X.2012.00937.x

Madejón, E., A.P. De Mora, E. Felipe, P. Burgos, and F. Cabrera. 2006. Soil amendments reduce trace element solubility in a contaminated soil and allow regrowth of natural vegetation. Environ. Pollut. 139:40-52. doi:10.1016/j.envpol.2005.04.034

Madejón, P., T. Marañón, J.M. Murillo, and B. Robinson. 2004. White poplar (Populus alba) as a biomonitor of trace elements in contaminated riparian forests. Environ. Pollut. 132:145-155. doi:10.1016/j.envpol.2004.03.015
Marschner, P. 2012. Marschner's mineral nutrition of higher plants. 3rd ed. Elsevier, London.

McLaren, R.G., L.M. Clucas, M.D. Taylor, and T. Hendry. 2005. Leaching of macronutrients and metals from undisturbed soils treated with metalspiked sewage sludge. 3. Distribution of residual metals. Aust. J. Soil Res. 43:159-170. doi:10.1071/SR04109

Metcalf, L.J. 1991. The cultivation of New Zealand trees and shrubs. Reed, Auckland, New Zealand.

Meurk, C.D. 2008. Vegetation of the Canterbury plains and downlands. In: N. Winterbourn, G. Knox, C. Burrows, and I. Marsden, editors, The natural history of Canterbury. Canterbury Univ. Press, Christchurch, New Zealand. p. $195-250$.

Meyer, V.F., E.F. Redente, K.A. Barbarick, R.B. Brobst, M.W. Paschke, and A.L. Miller. 2004. Plant and soil responses to biosolids application following forest fire. J. Environ. Qual. 33:873-881. doi:10.2134/jeq2004.0873

Montiel-Rozas, M.M., E. Madejón, and P. Madejón. 2015. Evaluation of phytostabilizer ability of three ruderal plants in mining soils restored by application of organic amendments. Ecol. Eng. 83:431-436. doi:10.1016/j. ecoleng.2015.04.096.

Moreno-Peñaranda, R., F. Lloret, and J.M. Alcañiz. 2004. Effects of sewage sludge on plant community composition in restored limestone quarries. Restor. Ecol. 12:290-296. doi:10.1111/j.1061-2971.2004.00310.x

Newman, R.F., M. Krzic, and B.M. Wallace. 2014. Differing effects of biosolids on native plants in grasslands of southern British Columbia. J. Environ. Qual. 43:1672-1678. doi:10.2134/jeq2014.01.0013

Obbard, J.P. 2001. Measurement of dehydrogenase activity using 2-p-iodophenyl-3-p-nitrophenyl-5-phenyltetrazolium chloride (INT) in the presence of copper. Biol. Fertil. Soils 33:328-330. doi:10.1007/s003740000332

Olsen, S.R., C. V. Cole, F.S. Watanabe, and L.A. Dean. 1954. Estimation of available phosphorous in soils by extraction with sodium bicarbonate. USDA Circ. 939. U. S. Gov. Print. Office, Washington, DC.

Pérez de Mora, A., J. Ortega-Calvo, F. Cabrera, and E. Madejón. 2005. Changes in enzyme activities and microbial biomass after "in situ" remediation of a heavy metal-contaminated soil. Appl. Soil Ecol. 28:125-137. doi:10.1016/j.apsoil.2004.07.006

Salmon, J.T. 1991. Native New Zealand flowering plants. Reed, Auckland, New Zealand.

Singh, R.P., and M. Agrawal. 2008. Potential benefits and risks of land application of sewage sludge. Waste Manag. 28:347-358. doi:10.1016/j. wasman.2006.12.010

Sopper, W.E., and L.T. Kardos, editors. 1973. Recycling treated municipal wastewater and sludge through forest and cropland. The Pennsylvania State Univ. Press, University Park, PA.

Walter, I., and R. Calvo. 2009. Biomass production and development of native vegetation following biowaste amendment of a degraded, semi-arid soil. Arid Land Res. Manage. 23:297-310. doi:10.1080/15324980903231827

Wang, H., M.O. Kimberley, and P.J. Wilks. 2013. Economic analysis of a pine plantation receiving repeated applications of biosolids. PLoS One 8:e57705. doi:10.1371/journal.pone.0057705

Wang, H., G.N. Magesan, M.O. Kimberley, T.W. Payn, P.J. Wilks, and C.R. Fisher. 2004. Environmental and nutritional responses of a Pinus radiata plantation to biosolids application. Plant Soil 267:255-262. doi:10.1007/ s11104-005-0107-4

Wardle, P. 1991. Vegetation of New Zealand. The Blackburn Press, Caldwell, NJ.

Xue, J., M.O. Kimberley, C. Ross, G. Gielen, L.A. Tremblay, O. Champeau et al. 2015. Ecological impacts of long-term application of biosolids to a radiata pine plantation. Sci. Total Environ. 530-531:233-240. doi:10.1016/j. scitotenv.2015.05.096 